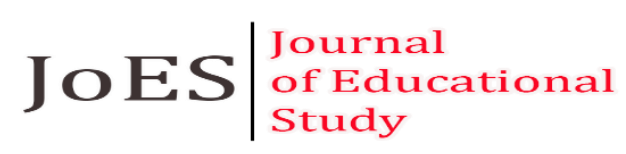

ISSN 2798-0650

Volume 2 Issue 12022

DOI: $10.36663 /$ joes.v2i1.268

\title{
Students' Difficulties in Writing Thesis During Covid-19 Pandemic
}

\author{
I Gusti Ayu Eka Susanti Dewi, Ganesha University of Education, Indonesia \\ ayu.eka@undiksha.ac.id
}

\begin{abstract}
The COVID-19 pandemic has had a significant impact on education where regulations in schools are increasingly being tightened to prevent the spread of the virus. This causes meeting access to be limited and even full of rules that must be obeyed. This condition certainly affects the data collection process in making a thesis, especially for students who research school. This study aims to find out the difficulties faced by 7th-semester students in writing a thesis during a pandemic. The approach used is qualitative research with in-depth interview techniques in data collection. The data were then analyzed descriptively from the results of the interviews. The results showed that the difficulties faced by students were the difficulty of access and permission to enter schools during the pandemic, the passive participation of research subjects, and the unequal distribution of information. From the result, it can be concluded that those three factors are the difficulties faced by students in writing a thesis during the COVID-19 pandemic. The researcher suggests conducting research on a larger scale and wider scope to the future researcher. This research is useful in redefining policies and actions that can be taken in overcoming the factors that make it difficult for students to research so that all aspects of education can work together.
\end{abstract}

Keywords: Difficulties, Thesis, Covid-19, Pandemic, Education

\section{Introduction}

In the world of education, there will always be final achievements that must be filled by the students as a graduation requirement which can be in various forms of work, depending on the level of education taken. In higher education in the undergraduate education program, a thesis is being the final requirement that must be done by students to be able to graduate and get a degree. Writing a thesis for undergraduate students is obligatory as a scientific study to apply theory, knowledge and create solutions to fulfill the framework of educational qualifications in Indonesia (Cahyadi et al., 2021). The idea behind making this thesis is as a form of encouragement for students to apply the knowledge they already have in their respective focus studies related to what they have been learned to produce new knowledge and discoveries (Quintana \& Hermida, 2020). The result of the research in the form of a thesis is then not only being a prerequisite for graduation but also contributes to an education field that makes knowledge keep growing.

In practice, final semester students often experience various challenges in writing a thesis. According to Thabran and Fajaryani (2017), writing a thesis is said to be the most 


\section{J OES $\mid \begin{aligned} & \text { Journal } \\ & \text { of Educational } \\ & \text { Study }\end{aligned}$}

ISSN 2798-0650

Volume 2 Issue 12022

DOI: $10.36663 /$ joes.v2i1.268

difficult part of a bachelor's career journey. Although students have been studying for years in the focus of their studies on how to make scientific writing and the skills needed, writing a thesis is not only a matter of applying but also a student's responsibility that must be completed as well as possible. Therefore, many factors need to be determined and considered carefully so that the thesis made can be trusted and qualified. According to Agricola et al., (2020), the positive perceptions of students can be built with empowerment and attention to social needs. This is very much needed to create sensitivity in capturing problems in studies' scope and improving their confidence in doing the thesis. However, the problems and challenges that are often experienced by students in the process of writing a thesis are often unavoidable. The factors that cause it are very diverse.

Several previous studies have studied and explored the difficulties of writing a thesis in a different research setting. In a study conducted by Puspita (2019), which examined the factors that influenced the difficulties of 49 students of the English study program at IAIN Curup in writing a thesis, it is found that linguistic factors were the most difficult cause of writing a thesis. This is because students still have difficulty in paraphrasing sentences from existing sources into their thesis. Another study conducted by Dwihandini et al., (2013), who examined the factors that affect the difficulty of writing a thesis for undergraduate students in the English department at Mahasaraswati University, found that psychological, sociocultural, and linguistic factors are the factors that make students have difficulty in writing a thesis. Meanwhile, in a research conducted by Kheryadi (2018) which investigated the problems faced by undergraduate students of the English study program at the University of Banten in making an introduction to a research proposal are the difficulty of presenting arguments in justification and students' less awareness of the standard or rules in writing a research proposal. In addition, Tiwari (2019) also conducted research related to the challenges faced by English students at Tribhuvan University in writing a thesis, then found that the unsupportive behavior of the supervisor and the difficulty of determining the scope of the study being the main challenges.

From the several studies that have been carried out, we can see that the difficulties or problems faced by students in writing a thesis can come from various factors and reasons, both internally and externally. For some research that requires going directly to the field, the environmental conditions in which the research is conducted will also be one of the determinants of the smooth running of the thesis. Since the COVID-19 pandemic hit the world, all areas of life have had a very significant impact included the education field (Tarigan, 2022). In response to the situation, all countries including Indonesia, have taken a policy to eliminate all educational activities and provide alternatives learning that can be taken (Abidah et al., 2020). All learning and teaching activities are carried out from their respective homes where distance learning is then applied. The use of various applications such as online lectures, online tutoring, and others are used in the learning process that is in line with the development of the industrial revolution era 4.0 (Dewi \& Wajdi, 2021). However, after two years have passed since the outbreak of the COVID-19 virus in 2019, the current COVID-19 cases are decreasing in Indonesia.

Many efforts keep conducted to stop the spread of COVID-19. The end of 2020 marked the beginning of the presence of the first dose of vaccine against the COVID-19 virus world market (Šiđanin et al., 2021). In September 2020, President Joko Widodo speaks in 


\section{J OES $\mid \begin{aligned} & \text { Journal } \\ & \text { of Educational } \\ & \text { Study }\end{aligned}$}

ISSN 2798-0650

Volume 2 Issue 12022

DOI: $10.36663 /$ joes.v2i1.268

front of PBB about the importance of access to vaccines to be able to end the Covid-19 pandemic (Wangke, 2021). The government cooperates with the scientific and medical community in administering vaccines (Gallè et al., 2021). Vaccination programs then started to be given to the entire general public, including children (Jacobvitz et al., 2002). After everyone got vaccinated, people worked again and the children went back to school (Muhyiddin \& Nugroho, 2021). The Ministry of Health has compiled a health protocol that must be obeyed by all people in face-to-face activities in public places (Ramadani et al., 2021). Schools in Indonesia have started conducting limited face-to-face learning at the end of 2021 with tightened regulations to prevent the spread of the virus. Students, teachers, and all staff at schools must comply with several rules such as the use of masks, physical distancing, reducing direct/touch interactions, hand hygiene, opening air vents/not being in closed rooms, cleanliness, disinfection, transportation to school, and management canteen (Lo Moro et al., 2020). In addition, Esposito et al., (2021) emphasized that schools must strictly comply with the recommendations of this virus prevention rule to optimize safe learning.

Strict school regulations during a pandemic certainly cause many restrictions to occur. Access in and out of people from outside the school is very controlled and must go through stages of checking requirements such as checking body temperature, vaccination certificates, mandatory use of masks, and also hand sanitizer. This condition makes some people who have the necessity in visiting schools for certain purposes very limited. If we return to the context of previous research that has been carried out, difficulties and problems in writing a thesis are still experienced by students even in normal situations without any pandemic or regulatory restrictions. Therefore, this study aims to find out what difficulties are faced by 7th-semester students in writing thesis during the COVID-19 pandemic which makes them face various strict rules, especially for students who conduct research at school. 5 students of the 7th semester are the subject of the research where the data are taken through in-depth interviews and will be analyzed descriptively. 7th-semester students were finally chosen because the current thesis work had been carried out as early as possible by students and many students had proposal exams in the 7th semester, and no longer in the 8th semester. Therefore, this study examines the difficulties experienced by students who have conducted thesis research earlier especially during this pandemic situation.

\section{Method}

This research was conducted through qualitative research of undergraduate students of the 7th semester in the English Language Education study program at Ganesha University. In this study, the researcher used an interview instrument which was conducted via telephone. Due to the pandemic situation, as cited in Azad et al., (2021), using the remote method through telephone interviews can be used as a means of data collection. Interviews can be a powerful way in which the data obtained are also a complex form of cultural formation, experience, language, age, gender, context, and others (Coleman, 2019). Data collection was taken using in-depth interviews to obtain in-depth and more detailed information. In-depth interviewing is one of the techniques in qualitative research in which interviews are conducted with an individual or a small number of respondents to explore a particular situation or their perspective on a topic (Boyce \& Neale, 2006). Moreover, according to (Roller, 2020), an in-depth interview is a method in which the interviewer engages in a one- 


\section{JOES $\begin{aligned} & \begin{array}{l}\text { Journal } \\ \text { of Educational } \\ \text { Study }\end{array} \\ & \text { Jtudion }\end{aligned}$}

ISSN 2798-0650

Volume 2 Issue 12022

DOI: $10.36663 /$ joes.v2i1.268

on-one dialogue with the interviewee to extract personal information from the person. The questions asked are usually controlled by the interviewer and the information obtained is then analyzed to produce a narrative or story about a particular topic of interest (Roller, 2020). The researcher then took important notes from the interviews. There are 5 participants in this study which are students who are making thesis, especially those who research primary schools. Data analysis focuses on the difficulties faced by participants and will be described descriptively. The researcher has analyzed the data using descriptive techniques from qualitative data analysis.

\section{Findings and Discussions}

The findings are presented in 3 major topics namely difficult access and permissions, passive participation, and unequal distribution of information. These findings are the main difficulties experienced by respondents in the process of writing a thesis and looking for data at schools during the COVID-19 pandemic.

\subsection{Difficult Access and Permissions}

This is related to the policies implemented in all schools in Indonesia regarding health protocols and the rules that apply to prevent the spread of the COVID-19 virus during the pandemic. This caused two respondents to have difficulty in finding data at the school where the study was conducted. According to respondents, their application for research permission was even rejected from several schools that had been targeted. This is because some schools apply strict regulations and safeguards to their students. They limit access to outsiders who do not work at the school. This condition makes it the undergraduate students difficult to find research places. For example, one participant said:

Several schools have rejected the research permits that have been submitted, they claim strict rules have been made to protect their students. However, some schools that also apply strict regulations still accept the presence of researchers, but the data collection can be done online only with the related teacher, and not allowed to come to school. (Female, 21 years old)

The pandemic situation has caused a reduction in research places for students who are researching schools. They have to deal with various rules that make the retrieval data might be not collected optimally if it is conducted online. In schools that accept the presence of outsiders but still limit interaction with the policy that data collection can only be done online, students have to readjust their research and research instruments that have been designed. This is certainly a challenge for students to strive in finding data in many limitations during the pandemic.

\subsection{Passive Participation}




\section{J OES $\mid \begin{aligned} & \text { Journal } \\ & \text { of Educational } \\ & \text { Study }\end{aligned}$}

ISSN 2798-0650

Volume 2 Issue 12022

DOI: $10.36663 /$ joes.v2i1.268

The participation of students and teachers in collecting research data is one of the other difficulties experienced by undergraduate students. Three participants admitted to having the same problem during the data collection process at school. When they interviewed students, students tend to answer modestly and are very passive in responding. This makes it students found difficult to have a dialogue with their research subjects. Passive participation is not only shown by students, some teachers also give passive responses when asked for information needed by students as researchers. Some teachers only answer with a single word with the answer "yes" repeatedly. For example, one participant said:

In conducting interviews, several subjects are not cooperative. Some teachers give monotonous answers by saying "yes" only. Meanwhile, students who are still in elementary school-age tend to ask back if they are given a question and some other students find it difficult to understand the questions asked. (Female, 22 years old)

Regarding participation and activeness, this is certainly influenced by distance learning which has been carried out for two years where students only study at home and do not interact and socialize with their surrounding environment. As cited in Gray and DiLoreto (2016), online learning makes students feel disconnected from their teachers and classmates. This tends to make students become individual and feel distrustful of the presence of new people or unknown people. In addition, according to Rahmawati et al (2021), distance learning has caused students to be lazy and shy in speaking so that their speaking skills decrease. Approaching students with this kind of psychology is certainly not an easy matter, especially if the research subjects are children who do not understand yet how to respond to someone well. Therefore, the passive participation of students and teachers is a challenge that must be faced by undergraduate students in collecting research data for the thesis.

\subsection{Unequal Distribution of Information}

Another difficulty faced by the five undergraduate students is the distribution of information that is not received by the subject evenly. For example, one participant said:

Sometimes the distribution of questionnaires was also a problem, because not all of the students have personal hand phones, so they have to wait for their parents. Some students don't even have a hand phone at their house, they have to borrow it from their neighbors to get information about their school. (Female, 21 years old)

This is because not all research subjects have personal hand phones, so the research instruments that are distributed do not reach all research subjects. Some subjects even live in very remote areas and far from the reach of the internet. Meanwhile, economically disadvantaged students don't even have a mobile phone at home, so that access to information can only be conveyed if the teacher visits the student's house directly. They have to face the reality of the lack of supporting facilities (Efriana, 2021). Students who do not have learning facilities ultimately do not know about the questionnaires or other research instruments that have been distributed. This cause the data collection cannot be collected thoroughly and optimally. This worrying fact is one of the challenges that students as researchers must face in completing data for their research. 


\section{JOES $\begin{aligned} & \begin{array}{l}\text { Journal } \\ \text { of Educational } \\ \text { Study }\end{array} \\ & \text { Otudion }\end{aligned}$}

ISSN 2798-0650

Volume 2 Issue 12022

DOI: $10.36663 /$ joes.v2i1.268

These three things are the difficulties faced by 7th-semester students in the process of writing a thesis, especially those who researching at school. They have to deal with strict regulations, passive research subjects, and also access to information that is not evenly distributed. During this pandemic, various challenges are increasing because we have to face new rules and conditions that have never been experienced before. However, the fact that during this pandemic period field research does encounter various kinds of difficulties is something that the researcher must overcome as much as possible.

\section{Conclusions and Suggestion}

This study aims to find out what difficulties are faced by 7 th-semester students in writing a thesis during a pandemic. In conclusion, it is found that five participants who researched schools experienced difficulties in terms of access and permissions, passive and unsupportive participation of research subjects, and unequal distribution of information. These are some of the realities they face in the process of writing their thesis during the COVID-19 pandemic, which makes them have to deal with school regulations and the psychological and material impacts of two years of distance learning. From this present study, researchers suggest to further researchers to conduct research on a larger scale and wider scope of research. So that this research does not only stop at the difficulty factor but can be developed by finding solutions that have been tested and can contribute to improving the quality of better learning during the pandemic.

\section{References}

Abidah, A., Hidaayatullaah, H. N., Simamora, R. M., Fehabutar, D., \& Mutakinati, L. (2020). The Impact of Covid-19 to Indonesian Education and Its Relation to the Philosophy of "Merdeka Belajar." Studies in Philosophy of Science and Education, 1(1), 38-49. https://doi.org/10.46627/sipose.v1i1.9

Agricola, B. T., Prins, F. J., van der Schaaf, M. F., \& van Tartwijk, J. (2020). Supervisor and Student Perspectives on Undergraduate Thesis Supervision in Higher Education. Scandinavian Journal of Educational Research, June, 1-21. https://doi.org/10.1080/00313831.2020.1775115

Azad, A., Sernbo, E., Svärd, V., Holmlund, L., \& Brämberg, E. B. (2021). Conducting indepth interviews via mobile phone with persons with common mental disorders and multimorbidity: The challenges and advantages as experienced by participants and researchers. International Journal of Environmental Research and Public Health, 18(22). https://doi.org/10.3390/ijerph182211828

Boyce, C., \& Neale, P. (2006). Conducting in-depth interviews: A guide for designing and conducting in-depth interviews for evaluation input. Pathfinder International Tool Series.

Cahyadi, S., Wedyaswari, M., Susiati, E., \& Yuanita, R. A. (2021). Why am I Doing My Thesis? An Explorative Study on Factors of Undergraduate Thesis Performance in Indonesia. Journal of Educational, Health and Community Psychology, 10(2), 351. https://doi.org/10.12928/jehcp.v10i2.19912

Coleman, P. (2019). In-depth interviewing as a research method in healthcare practice and education: Value, limitations and considerations. International Journal of Caring Sciences, 12(2), 1879-1885. 


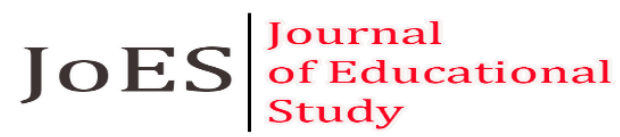

ISSN 2798-0650

Volume 2 Issue 12022

DOI: $10.36663 /$ joes.v2i1.268

Dewi, M. P., \& Wajdi, M. B. N. (2021). Distance Learning Policy During Pandemic Covid19. EDUTEC: Journal of Education And Technology, 4(3), 325-333. https://doi.org/10.29062/edu.v4i3.192

Dwihandini, L. A., Marhaeni, A. A. I. N., \& Suarnajaya, I. W. (2013). The Analysis of the Factors Affecting Undergraduate Students ' Difficulties in Writing Thesis in the English Department of Mahasaraswati. E-Journal Program Pascasarjana Universitas Pendidikan Ganesha, 2, 1-12.

Efriana, L. (2021). Problems of Online Learning during Covid-19 Pandemic in EFL Classroom and the Solution. JELITA: Journal of English Language Teaching and Literature, 2(1), 2721-1916.

Esposito, S., Cotugno, N., \& Principi, N. (2021). Comprehensive and safe school strategy during COVID-19 pandemic. Italian Journal of Pediatrics, 47(1), 4-7. https://doi.org/10.1186/s13052-021-00960-6

Gallè, F., Sabella, E. A., Roma, P., De Giglio, O., Caggiano, G., Tafuri, S., Da Molin, G., Ferracuti, S., Montagna, M. T., Liguori, G., Orsi, G. B., \& Napoli, C. (2021). Knowledge and acceptance of COVID-19 vaccination among undergraduate students from central and southern Italy. Vaccines, 9(6), 1-13. https://doi.org/10.3390/vaccines9060638

Gray, J. A., \& DiLoreto, M. (2016). The Effects of Student Engagement, Student Satisfaction, and Perceived Learning in Online Learning Environments This. NCPEA International Journal of Educational Leadership Preparation, 11(1), 98-119.

Jacobvitz, D., Curran, M., \& Moller, N. (2002). Measurement of adult attachment: The place of self-report and interview methodologies. Attachment and Human Development, 4(2), 207-215. https://doi.org/10.1080/14616730210154225

Kheryadi, K. (2018). The Student's Ability and Problems in Writing Introduction of Research Proposal. EEAL Journal (English Education and Applied Linguistics Journal), 1(1). https://doi.org/10.3389/fpsyg.2016.02056

Lo Moro, G., Sinigaglia, T., Bert, F., Savatteri, A., Gualano, M. R., \& Siliquini, R. (2020). Reopening schools during the COVID-19 pandemic: Overview and rapid systematic review of guidelines and recommendations on preventive measures and the management of cases. International Journal of Environmental Research and Public Health, 17(23), 1-21. https://doi.org/10.3390/ijerph17238839

Muhyiddin, M., \& Nugroho, H. (2021). A Year of Covid-19: A Long Road to Recovery and Acceleration of Indonesia's Development. Jurnal Perencanaan Pembangunan: The Indonesian Journal of Development Planning, 5(1), 1-19. https://doi.org/10.36574/jpp.v5i1.181

Puspita, C. (2019). Factors affecting students' difficuties in writing thesis A Mixed-Methods Research at Eighth Semester of English Study Program in IAIN Curup. 3rd English Language and Literature International Conference (ELLiC) Proceedings, 3, 13-22.

Quintana, L., \& Hermida, J. (2020). A Comparative Analysis of Undergraduate Thesis Courses in Canadian and Argentine Universities. 7(April), 30-37.

Rahmawati, Chanji Sihombing, Elya Karneda Br Ginting, E. A. (2021). the Effect of ELearning on Students Speaking Skill Progress: a Case of the Seventh Grade At Smp Pencawan Medan. Indonesian EFL Journal, 7(1), 69.

Ramadani, R., Hamzah, Y. A., \& Mangerengi, A. A. (2021). Indonesia's Legal Policy During COVID-19 Pandemic: Between the Right to Education and Public Health. JILS (Journal 


\section{J OES $\mid \begin{aligned} & \text { Journal } \\ & \text { of Educational } \\ & \text { Study }\end{aligned}$}

ISSN 2798-0650

Volume 2 Issue 12022

DOI: $10.36663 /$ joes.v2i1.268

of Indonesian Legal Studies), 6(1), 125-156.

Roller, M. R. (2020). The In-depth Interview Method. https://doi.org/10.5539/elt.v6n3p92

Šiđanin, I., Njegovan, B. R., \& Sokolović, B. (2021). Students' Views on Vaccination against COVID-19 Virus and Trust in Media Information about the Vaccine. The Case of Serbia. Vaccines, 9(12), 1430.

Tarigan, E. T. G. (2022). Impact of School from Home in Teaching and Learning English for Young Learners. Journal of Educational Study, l(3), 101-109. https://doi.org/10.36663/joes.v1i3.165

Thabran, Y., \& Fajaryani, N. (2017). Why It Took so Long to Complete Undergraduate Thesis at English Department: 82(Conaplin 9), 180-184. https://doi.org/10.2991/conaplin-16.2017.39

Tiwari, H. P. (2019). Writing Thesis in English Education: Challenges Faced by Students. Journal of NELTA Gandaki, 1, 45-52. https://doi.org/10.3126/jong.v1i0.24458

Wangke, H. (2021). Indonesia' S Vaccine Diplomacy for the World Health. International Relations Division:Info Singkat, A Brief Study of Actual and Strategic Issues, XIII(1), $17-12$. 